\title{
Fighting Corruption Through the Federal System: Independence as the Key to Corruption Eradication
}

\author{
Christopher Cason ${ }^{1}$ \\ \{174100401@uii.ac.id $\left.{ }^{1}\right\}$
}

Law Faculty, Universitas Islam Indonesia, Yogyakarta, Indonesia ${ }^{1}$

\begin{abstract}
Corruption is an age-old and persistent problem. While many nations have employed independent bodies dedicated to anti-corruption, with varying degrees of success, the United States has left its corruption eradication efforts to state and federal prosecutors charged with enforcing myriad anti-corruption statutes. While there is a large body of literature examining the effectiveness of dedicated anti-corruption agencies worldwide, there has been incomplete examination of how the United States' federal system of checks and balances and concurrent jurisdiction stacks up against agencies focused solely on anti-corruption. The Paper analyzes the constitutional framework and the Jurisprudence authorizing concurrent jurisdiction of corruption cases. The paper also looks at the practical impact of this system in contrast to other countries and concludes that there is no need or place for dedicated anti-corruption agency in the United States.
\end{abstract}

Keywords: Corruption, Federalism, Concurrent Jurisdiction.

\section{Introduction}

Corruption has been part of the human condition for as long as there has been money and government. Experts have traced original reports of corruption all the way back to the earliest civilization [1]. Corruption takes many forms, including bribery and kick-backs. Sadly, many have accepted corruption as a way of life, especially in developing countries. However, such apathy may come from the fact that few people understand the societal and economic impact of corruption. For society, corruption erodes confidence in democratic institutions, and disenfranchises the electorate. Economically, corruption increases the cost of doing business; it is estimated that corruption on average adds $10 \%$ to the cost of doing business and countries where corruption is high, receive 5\% less foreign investment. [2] Based on empirical research, a model has been developed to calculate the effect of corruption on GDP. The causative effect can be seen in Figure 1 below: [3] 


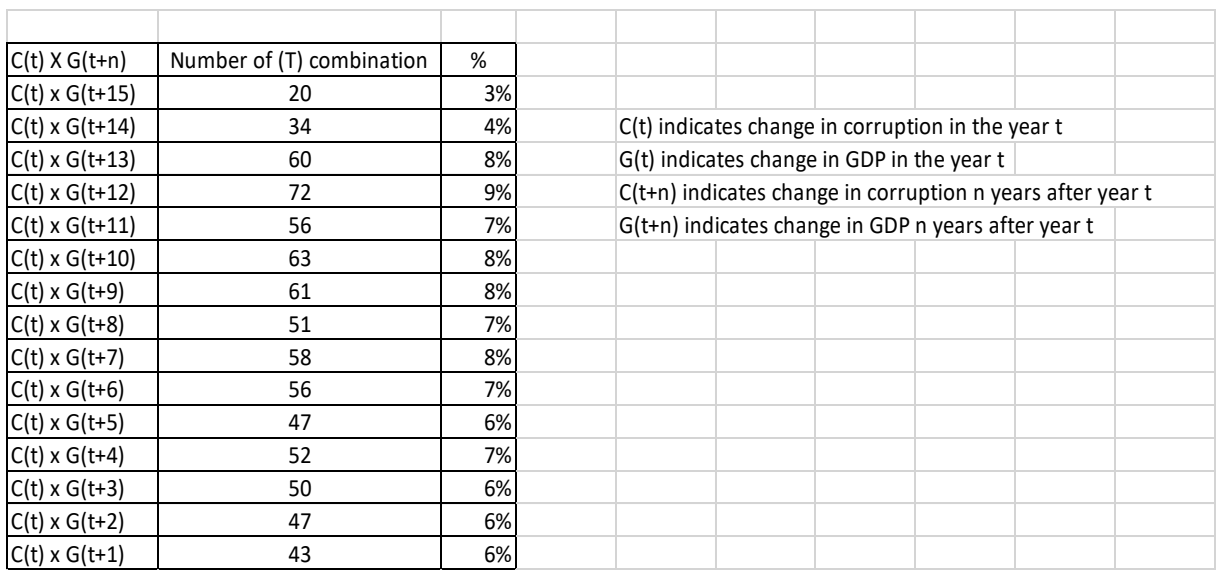

Figure 1 Model for Calculating The Effect of Corruption on GDP

This cost for individual nations can discourage foreign investment, crippling the economies of the developing nations hardest hit by corruption. Various nations have enacted laws and created bodies to fight corruption. Article 6 of The United Nations Convention against Corruption states:

1. Each State Party shall, in accordance with the fundamental principles of its legal system, ensure the existence of a body or bodies, as appropriate ...

2. Each State Party shall grant the body or bodies referred to in paragraph 1 of this article the necessary independence, in accordance with the fundamental principles of its legal system, to enable the body or bodies to carry out its or their functions effectively and free from any undue influence. The necessary material resources and specialized staff, as well as the training that such staff may require to carry out their functions, should be provided [3].

Both developed and emerging economies generally have commissioned specific government agencies to address corruption [4]. The effectiveness of these bodies have generally been limited [5]. There is a great deal of debate about the reasons for these agencies' success and failures [6]. First, it is important to briefly analyze different nations' approaches to policing corruption and their effectiveness at doing so. Only then can the American system be analyzed to determine its independence and coincident effectiveness. It appears that while anti-corruption agencies are solely focused on fighting corruption, they are often hindered by a lack of independence. The Federal System in the United States at minimum guarantees that such independence is constitutionally guaranteed and accordingly difficult to ameliorate.

\section{Literature Review}

Corruption and Economics. There appears to be a concrete correlation between the effectiveness of anti-corruption efforts in a nation and the economy of the nation. [2] Where nations have established anti-corruption agencies, there has been a corresponding decline in 
the amount of a nations gross domestic product that is wasted on corruption. [3] The United Nations has recognized this correlation. [4]

Effectiveness of Anti-Corruption Efforts. In contrast to the United States, many nations have adopted some form of government body charged with fighting corruption. The first Anti-Corruption Commission was established in Singapore in 1952, followed by Malaysia and Hong Kong, giving Asia the reputation as the "cradle" of Anti-Corruption Commissions. [7] In practice, unfortunately, these agencies generally fail to reduce corruption [4]. Indeed, the literature has "grown increasingly skeptical about their merits [8]."

There are many reasons for this failure: "[t]he absence of rule of law, accountability, and political will1 are considered as fundamental challenges for establishing effective" anticorruption agencies [8]. "[F] ew political leaders are able to bind themselves effectively to anti-corruption reforms over an extended period of time. Before too long, strong entrenched interests militate against the commission rendering it impotent or a tool to repress political opponents." Cambodia, Prime Minister Hun Sen used the campaign against illegal logging to remove those military officers who posed a threat to him. Likewise, opponents to the former Presidents of Indonesia and Malaysia were charged with corruption, as have opposition leaders in China and Vietnam [4].

The Federal System The federal system of government in the United States is enshrined in its constitution. Because the independence of individual states is guaranteed in the constitution, the legal systems of the 50 states cannot be taken away by the federal government [10]. This has essentially created a co-equal branch of government with the power to fight corruption. This power has repeatedly been reinforced by court rulings [11] [12].

\section{Methods}

The study explored how the Federal system of government can provide efficacy to anticorruption efforts. The study is premised on the relationship between the permanence of anti-corruption agencies and their relative effectiveness. The effectiveness of these agencies in-turn was measured by evaluating both the extent states are perceived as fighting corruption and the effect that corruption had on the economy.

Accordingly, the study employed empirical research of secondary sources to determine the effectiveness of various nations' anti-corruption efforts. In exploring the government structure of Federalism, the study applied a normative as well as statutory and conceptual methods.

\section{Result and Discussion}

\subsection{The Effectiveness of Anti-Corruption Agencies Is Directly Tied to Their Permanence and Independence}

Many anti-corruption agencies have been hamstringed by their ephemeral nature. Indeed, a majority of government agencies have been established under the guise of independence, their existence depends on the continued support of other agencies. [8] Indeed, many anti-corruption agencies are directly beholden to the very agencies and individuals they 
are ostensibly charged with investigating. [10] There have been many cases where anticorruption agencies were either completely disbanded, or undermined by inadequate funding or power. [6] Even worse, while public attacks on anti-corruption agencies has belied political claims of fighting corruption there is a darker underbelly where such agencies are more subtly torpedoed. [7] Without true independence and permanence any effort to fight corruption is toothless.

Where anti-corruption commissions have been successful, De Jaegere "argues that operational independence of [anti-corruption agencies] is the key requirement." [6] More generally there appears to be four underlying features that are key. [9] First, the impetus for an agency often arises from a precipitating crisis - such as a scandal involving the elite (a President, his/her family, or the Chief of Police, etc.) or a major financial crisis that generates widespread hardship - that drives popular support for reform. Such a broad-based coalition becomes a 'constituency for change.' Without a crisis, "building such a domestic coalition is a challenge for even the most popular leaders." Additionally, a state must already have a "free and robust media that can report about corruption without fear or favour." [5] Successful anticorruption organizations are also back by "political will," that is, a "genuine interest and confidence at the highest political levels about the benefits of having an independent and powerful anti-corruption agency." [10] Most importantly, a successful anti-corruption agency is formed with a charter giving it "the necessary combination of institutional independence, fiscal autonomy, and strong law enforcement powers, particularly in investigation.

These elements of success appear difficult to attain when the otherwise "independent" anti-corruption agencies serve at the pleasure of the legislative or executive branches of the government. [11] Anti-corruption provisions efforts are frustrated when faced with revoking a legislative charter.

\subsection{The United States System provides for independent prosecution of corruption crimes}

In order to avoid the "fox guarding the hen house" situation, those charged with fighting corruption must not be beholden to the individuals or agencies being monitored. Without independence, there can be no guarantee that perpetrators of corruption will be held accountable. The United States relies on its federal system of checks and balances contained in the constitution to provide a level of independence unavailable to Republics [12]. The Tenth Amendment to the Constitution requires a power-sharing form of government between the Federal, "central" government and the several states, stating "The powers not delegated to the United States by the Constitution, nor prohibited by it to the States, are reserved to the States respectively, or to the people [12]. This power sharing form of government means that states can act to prosecute corrupt individuals independent of the Federal government and vice versa. These powers are enshrined in the United States' constitution thereby solidifying their efficacy [13]. This power-sharing jurisdiction includes specific federal and state corruption statutes.

There are numerous federal criminal statutes to address corruption. These statutes include prohibition on bribery and colluding to violate corruption laws [14] [15] [16]. One unique aspect of the federal law is that it also prohibits United States entities from engaging in corruption outside its borders. The extraterritorial nature of the Foreign Corrupt Practices Act or FCPA was envisioned when enacted as a measure to fight corruption worldwide, and has even been criticized as hurting United States-based companies from competing abroad when 
hamstringed by the inability to pay bribes to local officials. [17] The Federal statutory framework generally provides comprehensive remedies for prosecuting acts of corruption.

The several states have similar, corresponding statutes. The statutes vary in language but the basic statutory framework is similar to their federal counterparts. [18] For example, Washington state's criminal code provides for separate crimes for bribery as well as ethical violations. [19] [20] [21] Because of the large number of company headquarters and organizations based in the state, New York sees many of the most high-profile prosecutions of public officials [22] [23] [24] [25]. The only area where the state laws vary significantly from federal laws is dealing with corrupt practices abroad.

Most often both the federal department of justice and at least one individual state will have concurrent jurisdiction over the same act of bribery. The Supreme Court in Tafflin v. Levitt decided that unless a federal statute specifically confers exclusive jurisdiction for federal courts, violations of federal statutes can be brought by state prosecutors. This case arose from the prosecution of a scheme to bribe regulators and defraud investors following the collapse of a savings and loan, the prosecutor brought a number of state law claims as well as a violation of RICO. The Court held that states generally possess concurrent jurisdiction to prosecute violations of federal statutes [26]. The progeny of the Tafflin decision has extended this concurrent jurisdiction to all federal corruption statutes unless the statute specifically reserves jurisdiction for the federal government. [27] [28] [29] [30] [31].

Essentially, this form of concurrent jurisdiction renders prosecutor's independent from the perpetrators of corruption. The major risk of a non-independent anti-corruption agency is that it would fail to prosecute corruption if it was related to or beholden to the accused perpetrator of corruption [32] [33] [34]. Generally, this has played out in situations where corruption in small jurisdictions was prosecuted by federal authorities where local prosecutors would not prosecute local government officials for fear of their own job security. Generally, Federal officials have been convicted of federal charges in Federal courts [35]. Of course, this independence would be at risk if the government could easily revoke this grant of power to the states as many anti-corruption agencies around the world have been stripped.

The effectiveness, however of the battle against corruption is that the independent, concurrent federal and state jurisdiction is protected by the constitution. The entire federal structure of the constitution grants this independence [36] [37]. To change this structure, would require a constitutional amendment. As evidenced by the fact that in its 230-year history, the United States Constitution has only been amended 27 times, amending the Constitution is a Herculean task [12]. To whatever extent, therefore, that the United States system of fighting corruption is effective is effective, is undisputed that at the very least the independent, power-sharing nation of the system is protected from the whims of whichever administration is in power.

\section{Conclusion}

Independence is the key to fighting corruption. While the United States does not have a designated body focused solely on fighting corruption, the power-sharing of the Federalist system, at a minimum, guarantees that prosecutorial bodies can be independent of the government they have authority over. While there are too many factors to draw a direct correlation between the form of corruption eradication system and the progress toward eradication of corruption, all nations can look to the ability to be independent with the ability 
to prosecute corrupt government officials. Those nations, whose corruption eradication commissions serve at the pleasure of the legislature or executive branches, are finding it difficult to remain independent.

\section{References}

[1] M. L. S. (Ed.), The Gift of Antiquity, Hoboken: John Wiley \& Sons, 2013.

[2] J. Lambsdorff, The Institutional Economics of Corruption and Reform: Theory, Evidence, and Policy, Cambridge: Cambridge University Press, 2007.

[3] D. Lučić, "Causality between corruption and the level of GDP," Economic Research-Ekonomska Istraživanja, vol. 29, no. 1, pp. 360-379, 2016.

[4] United Nations General Assembly, The United Nations Convention Against Corruption, New York: The United Nations, 2005.

[5] J. S. Quah, "Combatting Corruption in Asian Countries: What Lessons Have We Learned?," Public Administraiton \& Policy, vol. 16, no. 1, pp. 15-34, 2014.

[6] J. I. Odd-Helge Fjeldstad, "Anti-Corruption Reforms: Challenges, Effects, and the Limits of World Bank Support," The World Bank, Washington, 2008.

[7] S. D. Jaegere, "Principles for Anti-Corruption Agencies: A Game Changer," Jindal Journal of Public Policy, vol. 1, no. 1, pp. 83-85, 2012.

[8] J. John R. Heilbrunn, "Ant-Corruption Commissions: Panacea or Real Medicine to Fight Corruption?," World Bank Institute, Washington, 2004.

[9] "Assessing and Improving Performance of Anti-corruption Agencies," Anti-Corruption Resource Center, Bergen, Sophie A. Schutte.

[10] A. Strand, "An Exception to the Rule? Why Indonesia's Anti-Corruption Commission Succeeds Where Others Fail," U4 Institute, Bergen, 2010.

[11] J. S. Quah, "Benchmarking for Excellence: A Comparative Analysis of Seven Asian ACAs," World Bank Institute, Washington, 2009.

[12] A. Syakriah, "Majority of People Oppose KPK Law Revision, Support Student Protests, New Survey Reveals," The Jakarta Post, p. A1, 7 October 2019.

[13] The United States Government, The Constitution of the United States, Philidelphia: The Library of Congress, 1883 .

[14] J. e. a. Richard H. Fallon, The Federal Courts and the Federal System (6th Ed.), New York: Hart and Wechsler, 2009.

[15] The United States Goverment, Bribery of public officials and witnesses, 18 U.S. Code $\S 201$, Washington: The Library of Congress, 1994.

[16] The United States Government, Theft or bribery concerning programs receiving Federal funds, 18 U.S. Code $\$ 666$, Washington: The Library of Congress, 1994.

[17] The United States Government, Frauds and swindles, 18 U.S. Code $\$ 1341$ et seq., Washington: The Library of Congress, 1948.

[18] The United States Government, Foreign Corrupt Practices Act, 15 U.S. Code $\S 78 d d-1$, Washington: The Library of Congress, 1974.

[19] Working Paper, "Why Broad Definitions of Bribery Make Things Worse," University of Chicago Public Law Journal, vol. 502, no. 1, p. 9, 2015.

[20] The Government of the State of Washington, Official Misconduct, RCW 9A.80.010, Olympia: Washington State Archives, 2011. 
[21] The Government of the State of Washington, Bribery and Corrupt Influence, RCW 9A.68.010 et seq., Olympia: Washington State Archives, 2011.

[22] The Government of the State of Washington, Ethics in Public Service, RCW 42.52.010, Olympia: Washington State Archives, 1996.

[23] People v. Flanagan, 28 N.Y.3d 644, 2017.

[24] People v. Gordon, 72 A.D.3d 841, 2010.

[25] People v. Souvenir, 209 A.D.2d 455, N.Y.2d 447, 1994.

[26] People v. Charles, 61 N.Y.2d 321, 1984.

[27] Tafflin v. Levitt, 493 U.S. 455, 1990.

[28] McDonnell v. United States, 579 U.S.___ (slip op.), 2016.

[29] Arlington Central School Dist. Bd. of Ed. v. Murphy, 548 U.S. 291, 2001.

[30] United States v. Sun-Diamond Growers of Cal., 526 U.S. 398, 1999.

[31] McNally v. United States, 483 U.S. 350, 1987.

[32] United States v. Emmons, 410 U.S. 396, 1973.

[33] United States v. Fernandez, 722 F.3d 1 (1st Circuit), 2013.

[34] United States v. Selby, 557 F.3d 968 (9th Circuit), 2009.

[35] United States v. Starks, 472 F.3d 466 (7th Circuit), 2006.

[36] R. Fausset, "'It's the Human Way': Corruption Scandals Play Out in Big Cities Across U.S.," The New York Times, p. A12, 5 February 2019.

[37] E. E. Richter, "Exclusive and Concurrent Powers of the Federal Government," Notre Dame Law Review, vol. 4, no. 2, pp. 515-517, 1929.

[38] State of South Carolina v. United States, 50 Law. Ed. 261, 1905. 